\title{
Conserved RB functions in development and tumor suppression
}

\author{
Gabriel M. Gordon, Wei Du ${ }^{\bowtie}$ \\ Ben May Department for Cancer Research, University of Chicago, Chicago, IL 60637, USA \\ \ Correspondence: wei@uchicago.edu \\ Received October 3, 2011 Accepted October 18, 2011
}

\begin{abstract}
The variety of human cancers in which the retinoblastoma protein $\mathrm{pRb}$ is inactivated reflects both its broad importance for tumor suppression and its multitude of cellular functions. Accumulating evidence indicates that pRb contributes to a diversity of cellular functions, including cell proliferation, differentiation, cell death, and genome stability. pRb performs these diverse functions through the formation of large complexes that include E2F transcription factors and chromatin regulators. In this review we will discuss some of the recent advances made in understanding the structure and function of $p R b$ as they relate to tumor suppression, and highlight research using Drosophila melanogaster that reveals important, evolutionarily conserved functions of the RB family.
\end{abstract}

KEYWORDS RB, E2F, Drosophila Rbf, cell cycle, chromatin modification

\section{INTRODUCTION}

A decade and a half after Alfred Knudson proposed a two-hit hypothesis to explain the genetic events that give rise to cancer (Knudson, 1971), investigators were focusing on a region of chromosome 13 that was found to be deleted in a subset of retinoblastoma samples (Lalande et al., 1984) and discovered the precise location of the RB gene (Friend et al., 1986; Lee et al., 1987). In the years following these findings, intensive research efforts gave rise to a prevailing model in which the gene product $\mathrm{pRb}$ and its family members, $\mathrm{p} 107$ and $\mathrm{p} 130$, function as inhibitors of cell cycle progression (Table 1). These proteins function during $G_{1}$ by binding to the E2F family of transcription factors and generally repressing the expression of target genes by recruiting corepressors that regulate chromatin. Binding of $\mathrm{pRb}$ to E2Fs is inhibited by the activity of various cyclin-dependent kinases (CDKs), which are themselves activated by mitogen-induced expression of cyclins during the $G_{1}$ and $S$ phases of the cell cycle. Cdk4 or Cdk6, in complexes with D-type cyclins, initiate the progressive phosphorylation of $\mathrm{pRb}$, which generally correlates with an impaired ability to bind E2Fs (Ewen et al., 1993; Kato et al., 1993). Important E2F target genes that promote $G_{1} / S$ progression are $\mathrm{E}$ - and A-type cyclins which, in complexes with Cdk2, further target $\mathrm{pRb}$ for hyperphosphorylation in a positive feedback loop (Hinds et al., 1992). Whereas phosphorylation of $\mathrm{p} 107$ and $\mathrm{p} 130$ by CDKs causes their degradation during the cell cycle (Claudio et al., 2002), pRb is stable and becomes reactivated by phosphatase activity during mitosis (Ludlow et al., 1993).

The E2F transcription factors, encoded by at least eight distinct genes, are commonly thought of as either activators or repressors of transcription (Table 1). The activating and the repressive E2F proteins exhibit differential affinities for $\mathrm{RB}$ family proteins: activator E2Fs (E2F-1, -2, and -3a/b) interact primarily with $\mathrm{pRb}$ while repressor E2Fs (E2F-4 and -5) interact with $\mathrm{p} 107$ and $\mathrm{p} 130$. A further level of complexity is conferred by interactions with multiple members of the DP family of cofactors that are important for the ability of E2Fs (except E2F-7 and -8) to bind DNA (Attwooll et al., 2004; Du and Pogoriler, 2006). Additionally E2F-6, -7, and -8 do not have the capacity to bind RB family proteins. These atypical members of the E2F family are now known to have distinct roles that coordinate target gene expression during different cell cycle phases. For example, E2F-6 specifically represses E2F target genes during S-phase but not $\mathrm{G}_{2} / \mathrm{M}$ (Giangrande et al., 2004), while E2F-7 and -8 were recently shown to function together to repress the expression of a number of genes, notably E2F1 and CDC6, during the transition out of Sphase (Li et al., 2008). Despite these intricacies, work over the last decade has established a variety of genes as E2F 
Table 1 A list of the RB and E2F family genes and their regulators in Drosophila and mammals

\begin{tabular}{|c|c|c|c|}
\hline Gene family & Gene/alias (protein) & Fly ortholog & Conserved function(s) \\
\hline \multirow{3}{*}{ RB } & $\mathrm{RB} / \mathrm{Rb} / \mathrm{RB} 1$ (pRb) & Rbf/Rbf1 (Rbf) & $\begin{array}{l}\text { Transcriptional repressor; Binding both activator and } \\
\text { repressor E2Fs; DREAM complex formation? }\end{array}$ \\
\hline & P107/RBL (p107) & \multirow{2}{*}{ Rbf2 (Rbf2) } & Transcriptional repressor; Binding repressor E2Fs; \\
\hline & P130/RBL2 (p130) & & DREAM complex formation \\
\hline \multirow{4}{*}{$\mathrm{E} 2 \mathrm{~F}$} & $E 2 F-1,-2,-3(E 2 F-1,-2,-3)$ & $\mathrm{dE} 2 \mathrm{f} 1 / \mathrm{dE} 2 \mathrm{~F}(\mathrm{dE} 2 \mathrm{f} 1)$ & Transcriptional activation, repression; $\mathrm{pRb}$ binding \\
\hline & $E 2 F-4,-5(E 2 F-4,-5)$ & $\mathrm{dE} 2 \mathrm{f} 2(\mathrm{dE} 2 \mathrm{f} 2)$ & $\begin{array}{l}\text { Transcriptional repression; p107, p130 binding; DREAM } \\
\text { complex component }\end{array}$ \\
\hline & $\mathrm{E} 2 \mathrm{~F}-6(\mathrm{E} 2 \mathrm{~F}-6)$ & None & Repressor* \\
\hline & E2F-7, -8 (E2F-7, -8) & None & Repressor of E2F targets including E2F1* \\
\hline DP & TFDP $1-3(\mathrm{DP} 1-3)$ & $\mathrm{dDp}(\mathrm{dDp})$ & \multirow{2}{*}{$\begin{array}{l}\text { Cdk4, } 6 \text { activation, pRb phosporylation; Promotion of } \\
\mathrm{G}_{1} / \mathrm{S} \text { progression; Complex formation with Cip/Kip } \\
\text { CDK inhibitors }^{*}\end{array}$} \\
\hline D-type cyclin & CCND1-3 (Cyclin D1-3) & Cyclin D (dCycD) & \\
\hline E-type cyclin & CCNE1, 2 (Cyclin E1, 2) & DmCYCE (DmCycE) & $\begin{array}{l}\mathrm{G}_{1} / \mathrm{S} \text { transition }\end{array}$ \\
\hline \multirow{3}{*}{ Cip/Kip CDK inhibitor } & $\bar{C} \bar{D} \bar{K} \bar{N} \overline{1} \bar{A}(\bar{p} \overline{2} \overline{1} \bar{C} \overline{\mathrm{C}} \overline{\mathrm{p}} \overline{1} \overline{1})^{-}$ & \multirow{3}{*}{ DACAPO/DAP (Dap) } & \multirow{3}{*}{ 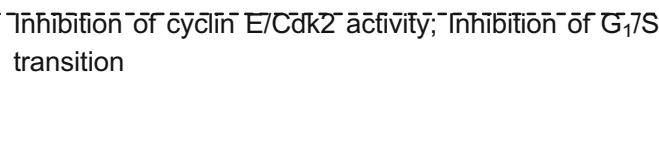 } \\
\hline & CDKN1B (p27/Kip1) & & \\
\hline & CDKN1C (p57/Kip2) & & \\
\hline \multirow{4}{*}{ INK4 Cdk inhibitor } & $\bar{C} \overline{\mathrm{K}} \bar{N} \overline{2} \bar{A}(\overline{1} \overline{1}-\bar{N}-\overline{4} \overline{4})$ & \multirow{4}{*}{ None } & \multirow{4}{*}{ 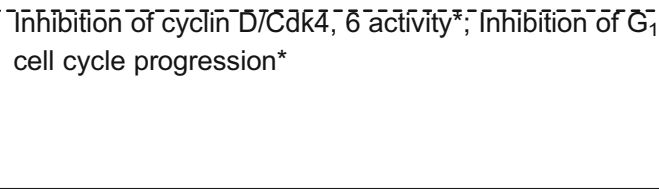 } \\
\hline & CDKN2B (p15-INK4b) & & \\
\hline & CDKN2C (p18-INK4c) & & \\
\hline & CDKN2D (p19-INK4d) & & \\
\hline
\end{tabular}

${ }^{*}$ Denotes function specific to mammals.

targets which have been broadly categorized into genes involved in S-phase progression and DNA replication, the spindle checkpoint and mitosis, DNA damage response, and apoptosis (Chen et al., 2009b), all functions that are highly relevant to cancer biology.

\section{Conservation of the RB-E2F pathway in flies}

Drosophila melanogaster is at the forefront of genetic research (Bier, 2005), as this important organism offers relative simplicity and a high level of conservation in $\mathrm{RB}$ and E2F families, cell cycle genes, and signal transduction pathways (Table 1). For example Rbf, which is orthologous to $\mathrm{pRb}$, interacts with both the activator-type dE2f1 and the repressor-type $\mathrm{dE} 2 \mathrm{f} 2$, and inhibits target genes involved in cell cycle progression, cell death, and other functions. On the other hand Rbf2, which interacts only with dE2f2 (Stevaux et al., 2002), seems to function more like p107 or p130. In addition to the two RB family genes and two E2Fs, flies have only a single DP. These features, coupled with a collection of well-developed genetic tools, make the fly a unique model to study conserved aspects of RB-E2F biology in vivo (van den Heuvel and Dyson, 2008). Accordingly recent studies using Drosophila have guided research in mammals to elucidate several important mechanisms of $\mathrm{pRb}$-mediated tumor suppression.

\section{RB INACTIVATION IN CANCERS}

\section{RB mutation or deletion}

Inherited RB mutations are found to cause a number of different tumors besides retinoblastoma (Burkhart and Sage, 2008), including osteosarcoma, which commonly arises in retinoblastoma patients as they age (Chauveinc et al., 2001). Retinoblastoma survivors are also predisposed to develop small cell lung cancer (SCLC) and actual RB loss is observed in the vast majority of SCLC cases (Kaye and Harbour, 2004). Interestingly this association contrasts with non-small cell lung cancer (NSCLC), in which loss of the RB gene is quite rare despite the frequency of functional inactivation of $\mathrm{pRb}$ by other means (Wikenheiser-Brokamp, 2006b). Studies using mouse models showed that $\mathrm{Rb}^{+/-}$animals develop neuroendocrine tumors and die early (Hu et al., 1994) and that $\mathrm{Rb}$ mutation cooperates with loss of either p107 or p130 in the development of a broader spectrum of tumors including retinoblastoma (Dannenberg et al., 2004). In addition $\mathrm{Rb}^{+/-}$, $\operatorname{Trp}_{53}{ }^{+/-}$mice also exhibit a slightly broader tumor spectrum. Although $\mathrm{Rb}^{+/-}$mice do not develop retinoblastoma, $\mathrm{Rb}^{+/-}$, $\mathrm{Trp}_{53}^{+/-}$mice exhibit retinal dysplasia (Williams et al., 1994). Further studies show that conditional deletion of $\mathrm{Rb}$ in a range of mouse tissues, including the retina, leads to apoptotic as well as hyperplastic phenotypes but that concomitant Trp53 
deletion often results in actual tumor growth (WikenheiserBrokamp, 2006a). Thus many tumors arising from RB loss, including retinoblastoma, appear to cooperate with p53 inactivation in both mouse models and human disease (Laurie et al., 2006; Burkhart and Sage, 2008).

Due to the prevalence of its mutation in retinoblastoma, osteosarcoma and SCLC, loss of RB is assumed to be an initiating event. But the majority of cancers in other tissues (for example, prostate, bladder, breast, etc.) display RB locus alterations less frequently, suggesting a role during disease progression in these cases (Burkhart and Sage, 2008). In support of this hypothesis recent studies found that loss of $\mathrm{pRb}$ expression due to RB deletion or, perhaps, epigenetic silencing (Kanber et al., 2009), is overrepresented in metastatic and castration-resistant prostate cancer (Sharma et al., 2010; Taylor et al., 2010). Loss of RB leads to ectopic expression of E2F target genes, including the angrogen peceptor in prostate cancer cells (Sharma et al., 2010) and cell cycle targets in breast cancers (Bosco et al., 2007), which results in deregulated cell proliferation, bypass of hormone deprivation therapy, and progression to hormone independence.

Regardless of whether inherited or somatic mutations of $\mathrm{RB}$ are involved in the initiation or progression of different cancers, some mechanism of $p R b$ inactivation is known to be a virtually universal feature of tumorigenesis (Sherr and McCormick, 2002).

\section{Functional inactivation of $\mathrm{pRb}$}

Whereas $\mathrm{pRb}$ function is inhibited by $\mathrm{D}-\mathrm{E}, \mathrm{E}-$, and A-type cyclins, these cyclin-CDK kinase activities are themselves regulated by two families of CDK inhibitors (CKIs) (Table 1). One is the p16 ${ }^{\operatorname{lnk} 4 a}$ family, which binds to Cdk4 and Cdk6 and thus inhibits the activity of D-type cyclins directed toward $\mathrm{pRb}$ (Serrano et al., 1993). Consistent with this, the ability of p16 to prevent cell cycle progression requires intact RB (Lukas et al., 1995). Another family of CKIs, including p $21^{\mathrm{Cip} 1}, \mathrm{p} 27^{\mathrm{Kip} 1}$, and p5 $7^{\text {Kip2 }}$, also interacts with cyclin/CDK complexes and inhibits cyclin E/Cdk2, cyclin A/Cdk2, and cyclin D/Cdk4 kinase activities (el-Deiry et al., 1993; Harper et al., 1993; Polyak et al., 1994; Toyoshima and Hunter, 1994). CKI expression is activated by diverse signals, such as the induction of $\mathrm{p} 21$ by p53 in response to DNA damage (Bunz et al., 1998), so the functions of these CKls highlight the essential role of $p R b$ in preventing cell cycle progression under normal circumstances as well as adverse conditions. Therefore frequent loss-of-function mutations affecting p16 or gain-of-function mutations affecting cyclin $D$ have the important result of inactivating $\mathrm{pRb}$ via hyperphosphorylation in many tumor types.

Although hyperphosphorylation of $\mathrm{pRb}$ apparently obviates the need for tumors to eliminate the RB gene, as evidenced by its expression in many cancers, recent data indicate that
$\mathrm{pRb}$ inactivation and $\mathrm{RB}$ deletion are not functionally equivalent. Comparisons between the molecular alterations in SCLC and NSCLC illustrate this notion. While the majority of NSCLC tumors display either $p 16$ loss or overexpression of cyclin $D$, most SCLC cases involve RB loss (WikenheiserBrokamp, 2006b). A potential explanation for this paradox is that the particular cell lineages that are affected by these diseases inherently differ in the relative importance of $p R b$ or p16 for their differentiation, and these differences could impact lung tumorigenesis (Wikenheiser-Brokamp, 2004). This could also be the case in other tissues, as pRb, for example, was shown to regulate the cell fate of mesenchymal progenitors and the lineage commitment of pre-osteoblasts (Calo et al., 2010). On the other hand, cooperating LOF mutations in TRP53 are more frequent in RB-deficient SCLC (Miller et al., 1992) and studies show that loss of RB, but not p16, results in the accumulation of DNA double strand breaks induced by deregulated E2F-1 (Pickering and Kowalik, 2006). However it is important to note that inactivation of p53 during NSCLC tumorigenesis could also be achieved by loss of p14 ${ }^{A R F}$ concomitant to genetic alterations of the p16/ CDKN2A locus (Kamijo et al., 1998; Stott et al., 1998; Zhang et al., 1998).

Another potential mechanism of RB inactivation is its epigenetic silencing. Previous studies showed that a $\mathrm{CpG}$ island in the RB promoter region is often found to be highly methylated in retinoblastoma cells compared to normal cells (Stirzaker et al., 1997), in agreement with several studies linking promoter hypermethylation, reduced $\mathrm{pRb}$ expression, and retinoblastoma (Feinberg and Tycko, 2004). Similarly, epigenetic silencing of Rbf has been shown to cooperate with Notch signaling in inducing metastatic tumors in a fly tumorigenesis model (Ferres-Marco et al., 2006). Therefore in addition to actual loss of the RB gene, epigenetic silencing or mutations of other components of the RB-E2F pathway are also important mechanisms of functional $\mathrm{pRb}$ inactivation in animal models and human cancers.

\section{pRb STRUCTURE AND ACTIVITY}

\section{E2F binding and regulation by cyclin-dependent kinases}

The 928-amino acid pRb consists of three recognizable structural domains, the $\mathrm{N}$ - and $\mathrm{C}$-terminal regions separated by a bipartite "small pocket." (Fig. 1A) The small pocket interacts with many of the known $\mathrm{pRb}$ binding partners, including E2F transcription factors, LxCxE motif-containing proteins such as viral antigens and histone-modifying enzymes, and cyclin-CDK kinase complexes (Goodrich, 2003). The small pocket domain itself is comprised of two major folds that are separated by a spacer region. Interestingly, the spacer is not well conserved between RB family paralogs, as this region contains consensus binding sites for CDKs in p107 and p130 but not pRb (Dynlacht et al., 1994; 
Zhu et al., 1995). The "large pocket," comprised of the small pocket together with the C-terminal domain, is both necessary and sufficient for the ability of $\mathrm{pRb}$ to inhibit cell cycle progression (Qin et al., 1992; Hiebert, 1993) and binding of the large pocket to cyclin-CDK complexes is mutually exclusive with the protein phosphatase PPc1 (Hirschi et al., 2010). Thus the pocket domain is the primary site for molecular interactions between $\mathrm{pRb}$ and binding partners that are either subject to its regulatory activity or are themselves regulators of $p R b$ function (Fig. 1A).

Despite difficulties in solving the structure of the entire $p R b$ protein, recent studies provide insight into how its different domains function and the consequences of phosphorylation for $\mathrm{pRb}$ activity. Identification of a novel interaction motif within the $\mathrm{N}$-terminus that consists of a tandem of folds similar to the small pocket region implies that the $\mathrm{pRb} \mathrm{N}$-terminus is capable of intramolecular interactions with the pocket (Hassler et al., 2007). Indeed, by demonstrating direct binding between these regions, this study suggests that $\mathrm{pRb}$ has a dynamic structure whereby the $\mathrm{N}$ - and C-termini may physically interact to form a closed conformation that is subject to post-translational modification. Additionally binding of EID-1, an LxCxE motif-containing inhibitor of histone acetylation, was shown to rely on interactions with both the pRb N-terminal and pocket domains (Hassler et al., 2007).
These results suggest a model of $p R b$ activity that relies on intramolecular interactions between the $\mathrm{N}$ - and $\mathrm{C}$-termini that are likely disrupted by phosphorylation or the binding of regulatory proteins.

Although the pocket region is known to be required for binding to many proteins, updated structural studies detail the effects of specific phosphorylation events, including those outside of the pocket, on pRb's conformation and binding to E2F/DP. The $p R b$ C-terminal domain interacts with regulatory domains within the E2F and DP families while the small pocket binds the E2F transactivation domain. Phosphorylation of $\mathrm{S} 788 / \mathrm{S} 795$ by cyclin D-Cdk4/6 during $\mathrm{G}_{1}$ partially destabilizes these interactions, and further phosphorylation of T821/T826 by cyclin D-Cdk4/6 or cyclin E/A-Cdk2 induces an intramolecular interaction between the small pocket and the C-terminus of pRb that excludes E2F/DP (Rubin et al., 2005). Additionally phosphorylation events from the $\mathrm{N}$-terminal to the small pocket (T356/T373), as well as within the pocket itself (S608/S612), are required for disruption of E2F transactivation domain binding. Importantly, deletion of the $\mathrm{N}$-terminal domain was observed to reverse the inhibitory effect of $\mathrm{pRb}$ phosphorylation on E2F transactivation domain binding in vitro (Burke et al., 2010). These results provide a more detailed mechanism of the phosphorylation-induced release of E2F/DP that allows S-phase progression.

A

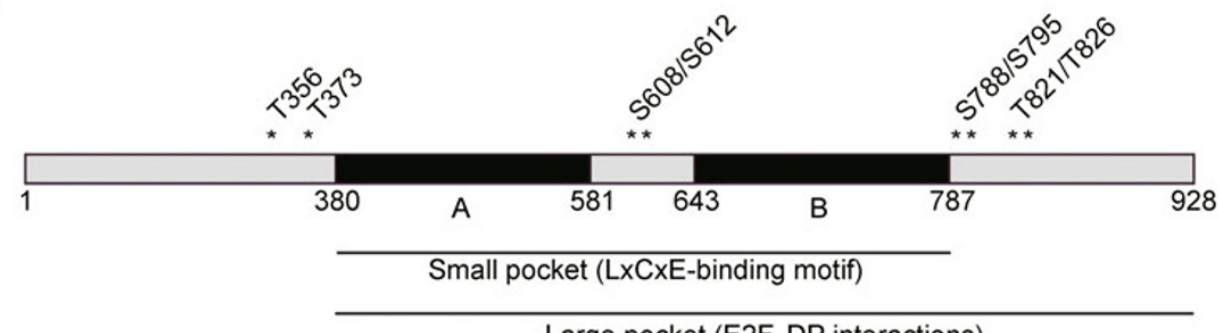

Large pocket (E2F, DP interactions)

B

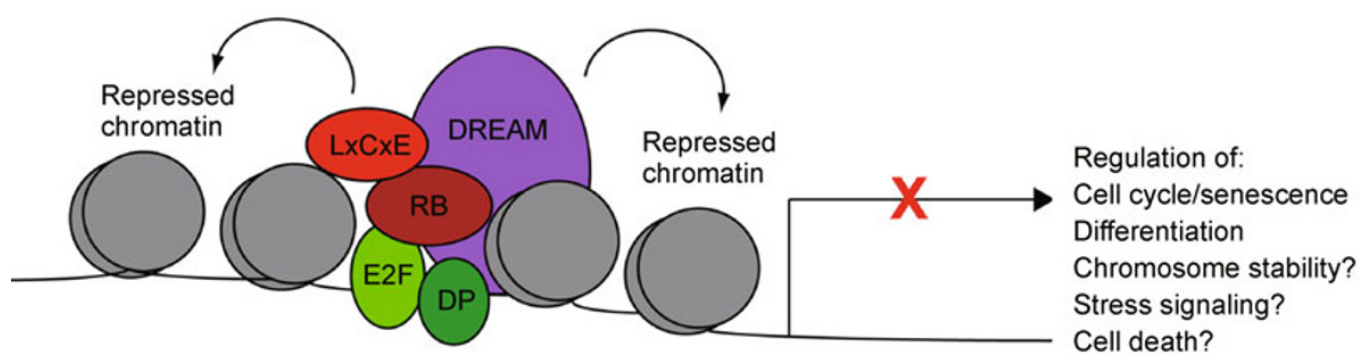

Figure 1. $\quad \mathrm{pRb}$ structure and function. (A) The structure of $\mathrm{pRb}$ consists of conserved $\mathrm{N}$-terminal and $\mathrm{C}$-terminal domains. The small pocket contains a tandem of folds, termed $A$ and $B$, that bind to E2F transactivation domains and LxCxE motifs that frequently occur in viral oncoproteins and chromatin regulators. The large pocket encompasses the small pocket and the $\mathrm{C}$-terminal domain that also interacts with E2F-DP complexes. Several important cyclin-dependent kinase target residues are indicated by asterisks. (B) Members of the RB family regulate gene expression in part by recruiting DREAM complexes and promoting chromatin repression. 


\section{Interactions with chromatin regulators}

In addition to its well-defined role of directly binding and inhibiting E2F activity, pRb has also been implicated in the general regulation of transcription by affecting chromatin dynamics. For example $\mathrm{pRb}$ can function as a transcriptional repressor by recruiting DNMT1 and promoting DNA methylation (Robertson et al., 2000), and reversing histone acetylation via recruitment of HDAC1 to gene promoters (MagnaghiJaulin et al., 1998). Histone acetylation is known to promote an open chromatin conformation and the expression of genes, including at least a subset of those controlled by E2F-1 (Takahashi et al., 2000; Zhang et al., 2000; Taubert et al., 2004). In addition, pRb was shown to directly interact with histone methyltransferases to promote heterochromatin and maintain chromosome fidelity (Gonzalo et al., 2005). Other experiments using a knock-in $\mathrm{Rb}$ allele that harbors a mutation in the LXCXE binding site show that this motif is important for the ability of $\mathrm{pRb}$ to bind a litany of histonemodifying enzymes, promote histone $\mathrm{H} 4 \mathrm{~K} 20$ trimethylation (a marker of repressive chromatin) at centromeres, and prevent chromosome fusions that lead to aneuploidy (Isaac et al., 2006). Subsequent studies indicate that the LxCxE-binding motif in $\mathrm{pRb}$ is also important for tumor suppression, as this knock-in allele causes chromosome instability (CIN) and accelerates loss of heterozygosity, tumor formation, and lethality in Trp53-mutant mice (Coschi et al., 2010).

Several groups identified another pRb-binding protein involved in chromatin regulation, $\mathrm{Rbp} 2$, which is one member of a family of proteins that act as histone $\mathrm{H} 3 \mathrm{~K} 4$ demethylases (Christensen et al., 2007; Iwase et al., 2007; Klose et al., 2007) whose enzymatic activity targets H3K4 trimethylation, a mark of transcriptionally active euchromatin (Ruthenburg et al., 2007). Rbp2 was shown to bind pRb via its LxCxE motif and affect the expression of genes specifically involved in differentiation (Benevolenskaya et al., 2005). Subsequent experiments revealed that Rbp2 is found at promoters harboring trimethylated $\mathrm{H} 3 \mathrm{~K} 4$ and knockdown of Rbp2 in RB-null cells promotes a differentiation gene expression program, similar to the effect of RB reintroduction. These studies indicate that $\mathrm{pRb}$ actually opposes the transcriptionally-repressive activity of Rbp2 during differentiation (LopezBigas et al., 2008). Later results showed that genetic ablation of $\mathrm{Rbp} 2$ impairs the proliferation of $\mathrm{Rb}^{-/-}$mouse embryonic fibroblasts (MEFs) while promoting differentiation and, importantly, mitigates neuroendocrine tumorigenesis in $\mathrm{Rb}^{+/-}$ animals (Lin et al., 2011). These reports indicate that $p R b$ has critical functions related to histone modification and chromatin regulation outside of inhibiting the $G_{1} / S$ transition.

Interestingly, some data implicate $\mathrm{pRb}$ as a transcriptional coactivator that targets genes involved in differentiation (Thomas et al., 2001; Calo et al., 2010), but a full understanding of the biological contexts in which $\mathrm{pRb}$ promotes gene expression is still lacking. Nonetheless it is now becoming clear that the ability to bind $\mathrm{LxCXE}$ motif-containing chromatin regulators is central to the role $\mathrm{pRb}$ plays as a regulator of gene expression (Fig. 1B). Indeed, the LxCxE binding region in $\mathrm{pRb}$ was very recently shown to be required for stress-induced senescence (Talluri et al., 2010) and cell cycle arrest following DNA damage, which was linked to tumor suppression in the liver (Bourgo et al., 2011). However the litany of LxCxE domain-containing proteins that are potential binding partners of $\mathrm{pRb}$ and the complexity of the $\mathrm{RB}, \mathrm{E} 2 \mathrm{~F}$ and DP family members in mammals are obstacles to comprehensively understanding important $\mathrm{pRb}$ functions, which has led to the utilization of alternative models to study RB-E2F biology.

\section{RB family proteins and DREAM/MMB complexes}

Concurrent studies sought to uncover components of a native Rbf complex using extracts from fly embryos, and identified a multimeric transcriptional repressor containing $\mathrm{dDp}$, Rbf/ Rbf2, dE2f2, and dMyb (hereafter DREAM) (Korenjak et al., 2004; Lewis et al., 2004). Both groups found that Rbf/Rbf2 copurified in DREAM complexes with multiple orthologs of MuvB, an evolutionarily-conserved gene class known to be important for vulval development in Caenorhabditis elegans. These studies revealed that DREAM complexes bind to transcriptionally inactive chromatin and repress E2F target gene expression. The results demonstrate that DREAM complex formation is an important function of RB family protein-mediated transcriptional repression in flies. Importantly DREAM complexes were also observed in human cells, where p130 was found to be the predominant RB family protein interacting with either of the two canonical repressive E2Fs, E2F-4 and E2F-5. Furthermore, DREAM complexes were found to occupy cell cycle-related E2F promoters and repress target gene expression in non-proliferating cells (Litovchick et al., 2007). Notably, two of these studies identified several HDAC transcriptional corepressors as DREAM components (Lewis et al., 2004; Litovchick et al., 2007). Despite some inconsistencies in the precise makeup of DREAM complexes, these studies established that RB family proteins participate in an important regulatory module that likely influences the formation of heterochromatin, a general feature of condensed and transcriptionally inactive DNA (Fig. 1B).

The notion that the importance of $\mathrm{pRb}$ for developmental gene expression is attributable to its role in coupling cell cycle exit with differentiation was disputed by a study that used Drosophila cells that were depleted for RB and E2F orthologs in culture. These experiments identified a group of genes that are regulated in proliferating cells by Rbf1, Rbf2, and dE2f2 (but not dE2f1) and are known to be involved in cell differentiation and tissue development (Dimova et al., 2003). Interestingly additional RNAi experiments indicate that many of these developmental genes are also subject to 
regulation by DREAM complexes, as their expression was observed to be dramatically increased upon knockdown of integral DREAM components (Korenjak et al., 2004). These studies have established RB family proteins as regulators of developmental genes independent of their cell cycle functions, but suggest that the ability to recruit chromatinregulating corepressors is important regardless of the affected transcription program.

\section{BIOLOGICAL FUNCTIONS OF RB}

\section{Regulation of cell cycle and senescence}

Although regulation of developmental gene expression can be achieved by RB family proteins in proliferating cells, exit from the cell cycle and entrance into quiescence is nevertheless an important aspect of terminal differentiation. Not only can $\mathrm{Rb}^{-1-}$ MEFs still arrest in $\mathrm{G}_{1}$ when cultured in the absence of serum (Mulligan and Jacks, 1998), but MEFs that lack all three RB-family genes arrest during $\mathrm{G}_{2}$ in response to serum starvation, owing to the induction of p21 and p27 expression by p53 (Foijer et al., 2005). These results indicate that the RB family functions together with the CIP/KIP family of CKls to achieve cell cycle arrest in the absence of mitogens. Furthermore, deletion of Rb, or even the collective loss of RB-family genes, is not sufficient to prevent cell cycle arrest during differentiation in mammals (Wirt et al., 2010).

Similar results were observed in experiments using the Drosophila model. The epidermal cells in fly embryos normally arrest in $G_{1}$ after the 16th mitotic cycle; however embryos lacking Dacapo (the fly CIP/KIP ortholog) fail to exit the cell cycle at this time while embryos lacking Rbf fail to maintain $G_{1}$ arrest (de Nooij et al., 1996; Lane et al., 1996; Du and Dyson, 1999). These findings indicate that both Rbf and Dacapo are required for normal cell cycle exit during Drosophila embryonic development. In addition, while mutation of either Rbf or Dacapo alone does not interfere with cell cycle exit in developing photoreceptor cells, mutation of both $\mathrm{Rbf}$ and Dacapo leads to ectopic $S$ phase entry (Firth and Baker, 2005). Furthermore, while Rbf-mutant tissue exhibits a delay in cell cycle arrest following differentiation, ectopic activation of cyclin E/Cdk2, in combination with dE2f1, is sufficient not only to prevent arrest but also to induce cell cycle re-entry (Firth and Baker, 2005; Buttitta et al., 2007). These results show that the regulation of the cyclin E/Cdk2 activity by Rbf and Dacapo is critical for both initiating and maintaining cell cycle exit during fly development.

$\mathrm{pRb}$ has also been reported to have E2F-independent functions that are important for coordinating the cell cycle. Direct interaction with $\mathrm{Cdh} 1$ facilitates $\mathrm{pRb}$ binding to components of APC/C, a complex important for the degradation of cell cycle substrates at the $G_{1} / S$ and $G_{2} / M$ checkpoints (Binnéet al., 2007). Cdh1 was previously shown to direct APC/C E3 ubiquitin ligase activity against Skp2, itself a component of an E3 ubiquitin-ligase complex, SCF (Wei et al., 2004). The ability of $\mathrm{pRb}$ to bind Cdh1 and promote the degradation of Skp2 was found to be important for cell cycle arrest due to a resultant accumulation of p27 (Binnéet al., 2007). Later experiments suggest that the regulation of Skp2 by $\mathrm{pRb}$ is relevant to tumor suppression as tumors arising in $\mathrm{Rb}^{+/-}$mice or targeted $\mathrm{Rb}^{-/-}$pituitary glands were completely suppressed by an $\mathrm{Skp2}^{-/-}$background, which was attributable to p27 stabilization and, at least in part, the subsequent induction of apoptosis (Wang et al., 2010). These studies indicate that cooperation between pRb and p27 is crucial for proper cell cycle regulation, differentiation, and tumor suppression.

$\mathrm{pRb}$ is known to be important for stress-induced senescence brought on by serum deprivation or oncogene activation (Sage et al., 2003), possibly by promoting heterochromatin formation and the stable repression of E2F target genes (Narita et al., 2003). Studies over the last several years have clarified how $\mathrm{pRb}$ contributes to this important mechanism of tumor suppression. One report using human diploid fibroblasts found a unique requirement for $\mathrm{pRb}$ in promoting oncogene-induced senescence. Cells coexpressing activated Ras and shRNA against RB exhibited deregulation of E2F target genes, including components of the DNA replication machinery and cyclin E, and aberrant S-phase entry. Interestingly neither p107 nor p130 knockdown is sufficient to induce either S-phase entry or deregulation of the DNA replication gene signature in Ras-expressing cells, providing a potential explanation for the predominance of RB mutations in cancer (Chicas et al., 2010). Another recent report showed that the tumor suppressor PML, which is important for Ras-induced senescence (Ferbeyre et al., 2000; Pearson et al., 2000), recruits activator E2Fs to PML nuclear bodies, inhibits expression of their target genes, and causes stable cell cycle exit in a pRb-dependent manner (Vernier et al., 2011). These results provide insight into the stability of $\mathrm{E} 2 \mathrm{~F}$ target gene repression by $\mathrm{pRb}$ in oncogene-induced senescence, but the details of how $\mathrm{pRb}$ interacts with specific cofactors to elicit irreversible cell cycle exit are still under investigation.

Further insight into how cells regulate $\mathrm{pRb}$-mediated cell cycle arrest and senescence comes from RB-deficient osteosarcoma cells that were engineered to re-express RB under an inducible promoter (Binnéet al., 2007). An shRNA screen using these cells sought to identify kinases that modulate $p R b$-enforced $G_{1}$ arrest and, over time, senescent phenotypes. Interestingly, a number of kinases were identified that are important for the establishment of senescence but not reversible $G_{1}$ arrest, including the Hippo pathway component and tumor suppressor LATS2. This study showed that LATS2 facilitates $\mathrm{pRb}$-mediated senescence by promoting the formation of p130/DREAM complexes at E2F target gene promoters and repressing transcription (Tschöp et al., 2011). These results coincide with another interesting study that 
implicates a non-canonical LATS2 kinase substrate, DYRK1A, in the formation of p130/DREAM complexes and establishment of oncogenic Ras-induced senescence (Litovchick et al., 2011). It is noteworthy that $\mathrm{p} 130$ and $\mathrm{p} 107$ individually were found to be dispensable for the senescence phenotype induced by oncogenic Ras (Chicas et al., 2010) yet these two proteins, but not $\mathrm{pRb}$, were found in DREAM complexes (Litovchick et al., 2007). It is possible that $p R b$ actually interacts with DREAM complexes in some contexts. Alternatively, $\mathrm{pRb}$ could be important for recruiting $\mathrm{p} 130$ - or p107-containing DREAM complexes to gene promoters, and that the distinct $\mathrm{p} 130$ and $\mathrm{p} 107$ complexes have redundant functions (Tschöpet al., 2011). Thus it remains unclear precisely how $\mathrm{pRb}$ promotes senescence via DREAM complex formation.

\section{pRb and the maintenance of genome stability}

In addition to regulating the cell cycle and establishing senescence, $\mathrm{pRb}$ also has important roles in both preventing genotoxic stress and responding to it. Indeed, the DNA damage response to aberrant replication is known to be critical for inducing senescence upon oncogene activation (Bartkova et al., 2006; Di Micco et al., 2006). A very recent study articulates another mechanism by which oncogenes disrupt $\mathrm{pRb}$ function and cause replicative stress during Sphase. This group showed evidence that inactivation of the $\mathrm{RB}$ protein family by expression of the HPV E6/E7 viral oncoproteins or cyclin $E$ causes uncoordinated $S$ phase entry with an insufficient pool of intracellular nucleotides. This leads to increased DNA replication stress, resulting in DNA damage and genome instability. Remarkably, addition of exogenous nucleosides or expression of genes such as C-Myc, which activates nucleotide biosynthesis genes, was found to rescue the observed replication stress and genome instability (Bester et al., 2011). These data present a mechanism for how tumorinitiating events such as inactivation of $\mathrm{pRb}$ can lead to premature S-phase entry, replicative stress, and the accumulation of DNA damage.

Several microarray-based approaches have identified E2F target genes, including those previously known to be involved in DNA replication and cell cycle control, as well as genes that are involved in chromatin condensation, chromosome segregation, spindle checkpoint, and components of the DNA damage checkpoint and repair pathways (Ishida et al., 2001; Ren et al., 2002). These observations suggest that $\mathrm{pRb}$ plays important roles in maintaining genome stability beyond its $\mathrm{G}_{1} / \mathrm{S}$ function. Indeed, the checkpoint protein Mad2, which senses improper kinetochore formation and regulates chromosome segregation during mitosis, was found to be a direct $\mathrm{E} 2 \mathrm{~F}$ target and is aberrantly expressed in cells with RB pathway inactivation, leading to mitotic defects and aneuploidy (Hernando et al., 2004). Deregulation of Mad2 was also recently shown to be important for chromosome instability observed in the absence of both Rb and Trp53 (Schvartzman et al., 2011).

In addition to regulating the expression of genes important for maintaining genome stability, $\mathrm{pRb}$ plays additional roles in promoting chromosome stability and preventing tumor growth in mice. The $L x C x E$ motif of $p R b$ was shown to be required for recruiting the CAP-D3 protein to centromeric heterochromatin, and this activity is important for promoting condensin II formation during mitosis and maintaining chromosome stability (Coschi et al., 2010). Importantly, these findings were supported by results from several other groups using flies (Longworth et al., 2008; Manning et al., 2010), human retinal cells (Manning et al., 2010) and the aforementioned $\mathrm{Rb}^{-/-}, \mathrm{p} 107^{-/-}, \mathrm{p} 130^{-/-}$TKO MEFs (van Harn et al., 2010). These interesting studies establish $\mathrm{pRb}$ functions in multiple cell cycle phases that are critical for promoting genome fidelity and tumor suppression.

\section{Controlling cell death}

$\mathrm{pRb}$ has long been appreciated to regulate cell death, a function that provides a failsafe mechanism against tumor formation in the event of its inactivation. E2F-1 activity is known to induce apoptosis in the absence of RB via multiple mechanisms and can promote the DNA damage response by transcriptional activation of $\mathrm{p} 14^{\mathrm{ARF}}$, which inhibits the degradation of p53 by Mdm2 (Bates et al., 1998). E2F-1 can also promote the response to DNA damage via p53 phosphorylation and activation independent of $\mathrm{p} 14^{\mathrm{ARF}}$ (Rogoff et al., 2002). However cell death induced by E2F-1 is not universally dependent on TRP53 (Ginsberg, 2002), as it also has well-documented roles in the regulation of initiator (Moroni et al., 2001) and effector caspase function (Müller et al., 2001), as well as mitochondrial membrane integrity (Stanelle et al., 2002).

Research in the last several years has provided insight into the contexts in which $\mathrm{pRb}$ operates as an inhibitor of cell death. Studies in Drosophila show that Rbf represses expression of $\mathrm{Hid}$, a member of an apoptotic gene family that functions to inactivate the Drosophila inhibitor of apoptosis proteins (DIAP), similar to mammalian Smac/ Diablo. However, the mechanism of Hid regulation and apoptosis differs among cell types and developmental contexts, as E2F function was shown to be important for both cell death and survival (Moon et al., 2005; Moon et al., 2006; Tanaka-Matakatsu et al., 2009; Li et al., 2010). These studies reflect a conserved and complex role for E2Fs in controlling Smac/Diablo expression (Xie et al., 2006; Chen et al., 2009a).

Studies using E2f-1, -2, -3 TKO mice showed that activator E2Fs may actually have a survival function during retinal development, as cells from this tissue exhibit reduced 
expression of Sirt1, which functions to block p53 acetylation and function, leading to increased apoptosis (Chen et al., 2009a). A later study yielded similar results using independently-derived E2f-1, -2, -3 TKO mice, and shed light on the collective function of activator E2Fs during intestinal differentiation. These experiments showed that progenitor cells can proliferate in the absence of activator E2Fs, but they accumulate DNA damage, leading to p53-independent apoptosis. Interestingly, differentiated E2f-1, $-2,-3$ TKO cells in the intestine do not proliferate or exhibit apoptosis, suggesting that the ability of activator E2Fs to prevent cell death is limited to the undifferentiated cells (Chong et al., 2009). Thus the functions of E2Fs as inducers of apoptosis are highly dependent on context and $\mathrm{pRb}$, by extension, may have roles either to promote or inhibit programmed cell death.

Indeed, recent results from Drosophila show that Rbf expression induces apoptosis in proliferating cells but not in post-mitotic cells through a caspase-dependent mechanism (Milet et al., 2010). Similarly, pRb was recently shown to promote apoptosis in proliferating cells treated with the DNAdamaging agent doxorubicin in mammals. In these experiments hyperphosphorylated $\mathrm{pRb}$ was found in a complex with E2f-1 and the histone acetyltransferase P/CAF bound to transcriptionally-active caspase 7 and p73 promoters, and intact $\mathrm{Rb}$ was shown to be required for the DNA damageinduced apoptotic phenotype (lanari et al., 2009).

\section{MODULATION OF RB LOSS BY CELLULAR SIGNALING NETWORKS}

The functions of RB during the cell cycle, apoptosis, and differentiation are exerted within the context of cellular signaling networks, which will influence the outcome of RB pathway deregulation. Elucidating the key signaling events that can influence the effects of RB loss will provide new insights into the functions of $\mathrm{pRb}$ in different settings and potentially provide new ways of intervention in cancer treatment.

\section{Cell survival in the absence of $\mathrm{RB}$}

Deregulation of activator E2Fs plays a key role in tumorigenesis following $\mathrm{Rb}$ loss, as evidenced by $\mathrm{Rb}^{-1}$, E2f-1 $1^{-1-}$ knockout mice. These animals survive longer than $\mathrm{Rb}^{-/-}$mice due to reduced apoptosis in multiple tissues (Tsai et al., 1998). Additionally an E2f-1 ${ }^{-/-}$genetic background extends lifespan and reduces tumor incidence in $\mathrm{Rb}^{+/-}$mice (Yamasaki et al., 1998). Because E2f-1 $1^{-/-}$mice themselves are also apoptosis-defective and tumor-prone (Yamasaki et al., 1996), the proliferative function of E2f-1 is likely important for tumorigenesis downstream of $\mathrm{Rb}$ loss. Therefore in addition to the regulation of proliferation, inhibition of E2f-1-induced cell death is a critical function of $p R b$ during development and loss of these functions is tumorigenic when cell death is compromised by various mechanisms. As mentioned above, a number of E2F-1 target genes involved in apoptosis have been identified. Therefore, considerable attention in recent years has been paid to signaling pathways that have the ability to affect the apoptotic E2F transcription program. Notably, the Drosophila model is at the forefront of these investigations.

Previous experiments using cultured Rb, p107, p130 TKO MEFs showed that cell death caused by serum deprivation can be reversed by expression of activated Ras through multiple effectors (Young and Longmore, 2004). Interestingly studies using Drosophila show that epidermal growth factor receptor (EGFR)/Ras signaling is also important for suppressing apoptosis observed in the absence of the Rbf during fly retinal development. It was shown that genetic deregulation of Ras signaling or overexpression of Raf is sufficient to prevent the death of Rbf-deficient cells in vivo (Moon et al., 2006). It should be pointed out that while Ras signaling counteracts apoptosis induced by the loss of RB in both flies and mammals, the precise mechanisms downstream of Ras that regulate apoptosis are divergent. In Drosophila, EGFR/Ras counteracts apoptosis of Rbf-deficient cells through mitogen activated protein kinase (MAPK), which phosphorylates and inactivates $\mathrm{Hid}$, a key death inducer in cells with deregulated E2F activity (Bergmann et al., 1998; Moon et al., 2005; Moon et al., 2006; Tanaka-Matakatsu et al., 2009). On the other hand, pharmacological inhibition of ERK was not sufficient to reverse the protective effect of Ras on Rb, p107, p130 TKO MEFs cultured in low serum. In fact, the ability of Ras signaling to counteract the apoptotic effect of Rb loss may depend on phosphatidylinositol 3-kinase (PI3K) activity (Young and Longmore, 2004).

Experiments designed to investigate the effect of $\mathrm{PI} 3 \mathrm{~K}$ signaling on E2F-1-induced gene expression showed that a subset of E2F target genes are specifically repressed upon serum-induced PI3K activity. Many of these genes have apoptotic functions, as opposed to proliferative genes that are not affected by PI3K activity, suggesting that PI3K survival signaling is an important response to deregulation of E2F-1 during tumorigenesis. Indeed, reduced expression of many genes in this cohort were shown to correlate with poorer clinical outcomes for breast and ovarian cancer (Hallstrom et al., 2008). One of the interesting genes to come out of this analysis was Ampka2, a gene encoding the catalytic subunit of the energy-sensing kinase AMPK (AMP-activated protein kinase). Knockdown of Ampka2 was observed to reduce E2F-1-induced apoptosis in cultured cells either deprived of serum or treated with the AMPK agonist AICAR (Hallstrom et al., 2008). Therefore deregulated PI3K signaling can potentially affect the apoptotic E2F-1 transcriptional program and cooperate with loss of RB in promoting tumorigenesis.

PI3K/Akt signaling regulates diverse cellular functions including cell growth, survival, and metabolism. PI3K/Akt signaling has many established feedback loops that prevent 
excessive activation of the Akt oncogene in the event of mTOR deregulation (Harrington et al., 2004; Shah et al., 2004; Sarbassov et al., 2005; Julien et al., 2010; Treins et al., 2010). Interestingly, although activation of PI3K/Akt can suppress cell death induced by a variety of signals, increased Akt signaling also sensitizes cells to reactive oxygen species (ROS)-induced death (Nogueira et al., 2008). In addition, loss of either TSC1 or TSC2 induces ER stress and increases the sensitivity of TSC1/TSC2-mutant cells to apoptosis (Ozcan et al., 2008). Recent work in our lab and others showed that deregulated TORC1 activity downstream of TSC1 and TSC2 (Hsieh et al., 2010; Li et al., 2010) promotes cell death in the absence of Rbf during fly development. This effect is conserved in human cells, as the loss of both RB and TSC2 also causes "synthetic lethality," a general feature whereby cells that harbor the mutation of a particular tumor suppressor such as RB become reliant on specific genes for survival (Kaelin, 2005). We found that knockdown of TSC2 specifically kills a variety of cancer cells that lack RB under stress conditions and prevents tumor formation in vivo. While previous studies implicated $\mathrm{pRb} / \mathrm{E} 2 \mathrm{~F}$ in the regulation of oxidative (Tanaka et al., 2002) and ER stress (Racek et al., 2008), we observed that inactivation of $p R b$ causes downregulation of the ROS scavenger SOD2 while knockdown of TSC2 leads to increased levels of both ROS and ER stress. Importantly, the high level of cellular stress resulting from the combined inactivation of RB and TSC2 contributes to this synthetic cell death (Li et al., 2010). As mentioned above, TSC2 inactivation also results in the downregulation of Akt activity. Although our results in prostate cancer cells do not implicate reduced Akt signaling in the synthetically lethal relationship between $\mathrm{pRb}$ and $\mathrm{TSC} 2$, it is possible that decreased PI3K/Akt activity resulting from feedback regulation contributes to reduced survival in other cell types (Fig. 2).

\section{RB loss and differentiation}

Recent results in our lab show that Rbf is important for proper photoreceptor differentiation when developmental pathways such as Notch and EGFR signaling are compromised in the Drosophila retina. Rno is an EGFR pathway component required for expression of the Ets transcription factor Pointed, which is important for EGFR/Ras signaling in the nucleus. Pointed also controls expression of Argos, a feedback inhibitor that functions to limit Ras signaling (Voas and Rebay, 2003; Sukhanova et al., 2011). We found that the phenotype of mutant Rno, while subtle on its own, synergizes with the loss of Rbf and leads to defective R8 photoreceptor determination and subsequently delays photoreceptor differentiation (Steele et al., 2009; Sukhanova et al., 2011). Our data indicate that loss of Rbf reduces expression of Rhomboid, a transmembrane protein important for EGFR ligand processing. Reduced Rhomboid levels attenuate

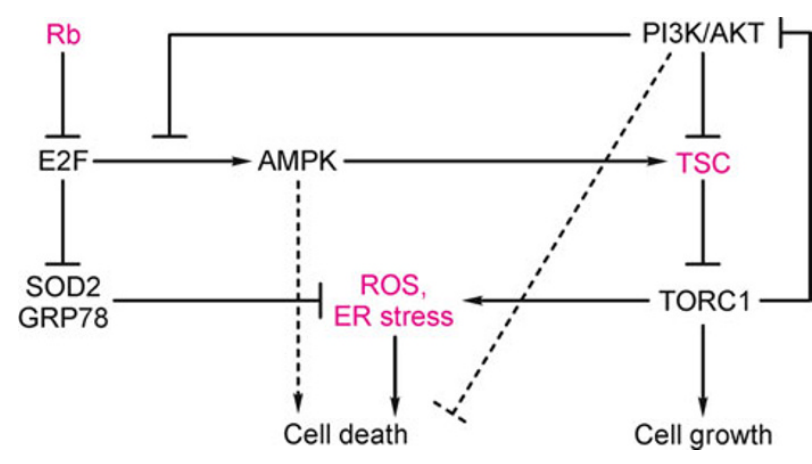

Figure 2. Dependence of RB-deficient cells on TORC1 regulation. $\mathrm{pRb} / \mathrm{E} 2 \mathrm{~F}$ participates in oxidative stress and unfolded protein responses by promoting expression of the ROS scavenger SOD2 and ER chaperone GRP78, respectively. Therefore cells harboring RB mutations are more sensitive to ROS- and ER stress-induced death. Because loss of TSC function causes deregulated TORC1 activity, which induces increased cellular stress and feedback inhibition of PI3K/AKT survival, RB-deficient cells are sensitive to the loss of either TSC1 or TSC2 and show synthetic lethality.

activation of MAPK in the cytoplasm which, in combination with abrogated EGFR signaling output in the nucleus due to the loss of Rno, synergistically delays photoreceptor differentiation (Sukhanova et al., 2011). These results suggest an important function of Rbf in terminal differentiation that is independent of its role in cell proliferation (Fig. 3).

Rbf was also shown in recent reports to cooperate with the Hippo tumor suppressor pathway to promote differentiation during fly retinal development. These experiments demonstrated that loss of Wts, the fly ortholog of the aforementioned LATS2 kinase, suppresses apoptosis, enhances proliferation, and antagonizes differentiation in Rbf-mutant eye tissue. Importantly, the impaired differentiation phenotype was observed to be independent of the proliferative effect, as expression of numerous photoreceptor differentiation markers was still diminished in the absence of dE2f1 (Nicolay et al., 2010). This group also showed in a subsequent report that $\mathrm{dE} 2 \mathrm{f1}$ and Yki (the fly ortholog of the YAP transcription factor) cooperate to activate a particular gene expression signature, including a number of cell cycle-related targets, and this collaborative function is repressed by Rbf (Nicolay et al., 2011). These results, combined with the experiments described above implicating cooperative LATS2 and pRb activity in DREAM complex formation, suggest that members of the RB family function as critical regulators of proliferation while promoting differentiation upon activation of Hippo signaling, a pathway that has garnered significant recent attention for its role in cancer (Pan, 2010; Dick and Mymryk, 2011). 


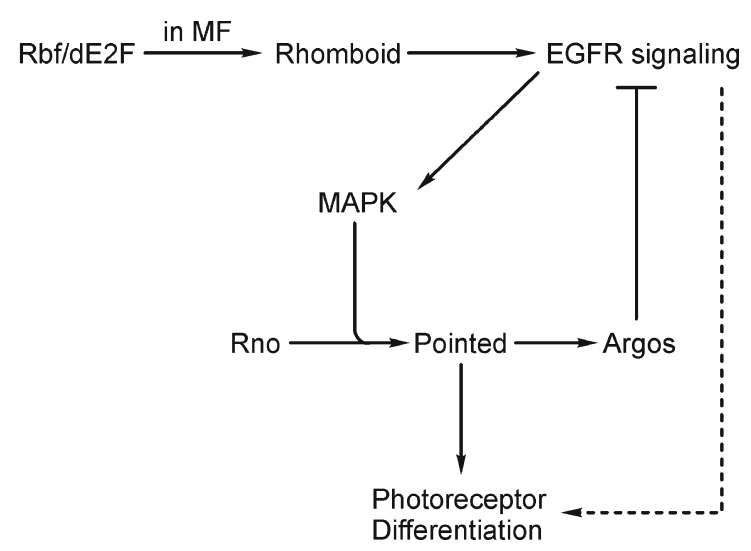

Figure 3. Control of Drosophila photoreceptor differentiation by Rbf and Rno. Rbf is required for the high level of Rhomboid expression in the morphogenetic furrow (MF), although reduced cytoplasmic epidermal growth factor receptor (EGFR) signaling is apparently sufficient to induce photoreceptor differentiation. Rno is required for the transcription of Pointed, an Ets-family transcription factor that is important for photoreceptor differentiation. However Pointed is also required for the expression of Argos, a negative regulator of EGFR signaling. Thus the impairment of EGFR signaling output in the nucleus due to Rno mutation is mitigated by reduced feedback inhibition of EGFR in the cytoplasm. Loss of both Rbf and Rno together affects both cytoplasmic and nuclear components of EGFR-Ras signaling, leading to defective photoreceptor differentiation.

\section{CONCLUDING REMARKS}

Much progress has been made in recent years toward understanding the wide variety of $\mathrm{pRb}$ functions, especially those that are important for tumor suppression. However four decades after Knudson published his seminal work on retinoblastoma, there is still much to be learned about the dependence of cancer on the many different mechanisms of $\mathrm{pRb}$ inactivation. Notably, recent cancer genome sequencing data (Chin et al., 2011) suggest that while a few common pathways (including RB-E2F) are often affected in cancer, large numbers of additional mutations are observed in any individual tumor. The possibility that such mutations or combinations of mutations can cooperate with inactivation of $\mathrm{pRb}$ to affect critical cellular processes is quite high. Thus continued research into how parallel signaling pathways modulate the affects of deregulated E2F activity on cell proliferation, differentiation, and cell death could help to illuminate how particular genetic outcomes of $\mathrm{pRb}$ inactivation contribute to tumorigenesis in humans and, potentially, identify novel targets for therapeutic intervention (Knudsen and Wang, 2010; Searle et al., 2010; Gordon and Du, 2011). Therefore it is incumbent on researchers to push forward in the pursuit of a comprehensive understanding of the RB-E2F pathway in actual biological contexts. Given the universality of $\mathrm{pRb}$ defects in cancer, such an understanding will hopefully translate into a range of effective treatments for specific genetic alterations, yielding improvements to patient quality of life in the future.

\section{ACKNOWLEDGEMENTS}

This work is supported in part by grants from the National Institutes of Health (RO1CA149275, RO1GM074197, PO1AT004418) and a grant from DOD (W81XWH-10-1-0077) to WD.

\section{ABBREVIATIONS}

AMPK, AMP-activated protein kinase; CDKs, cyclin-dependent kinases; CKIs, CDK inhibitors; CIN, chromosome instability; EGFR, epidermal growth factor receptor; ER, endoplasmic reticulum; MAPK, mitogen activated protein kinase; MEFs, mouse embryonic fibroblasts; PI3K, phosphatidylinositol 3-kinase; ROS, reactive oxygen species

\section{REFERENCES}

Attwooll, C., Lazzerini Denchi, E., and Helin, K. (2004). The E2F family: specific functions and overlapping interests. Embo J 23, $4709-4716$.

Bartkova, J., Rezaei, N., Liontos, M., Karakaidos, P., Kletsas, D., Issaeva, N., Vassiliou, L.V., Kolettas, E., Niforou, K., Zoumpourlis, V.C., et al. (2006). Oncogene-induced senescence is part of the tumorigenesis barrier imposed by DNA damage checkpoints. Nature 444, 633-637.

Bates, S., Phillips, A.C., Clark, P.A., Stott, F., Peters, G., Ludwig, R.L., and Vousden, K.H. (1998). p14ARF links the tumour suppressors RB and p53. Nature 395, 124-125.

Benevolenskaya, E.V., Murray, H.L., Branton, P., Young, R.A., and Kaelin, W.G. Jr. (2005). Binding of pRB to the PHD protein RBP2 promotes cellular differentiation. Mol Cell 18, 623-635.

Bergmann, A., Agapite, J., McCall, K., and Steller, H. (1998). The Drosophila gene hid is a direct molecular target of Ras-dependent survival signaling. Cell 95, 331-341.

Bester, A.C., Roniger, M., Oren, Y.S., Im, M.M., Sarni, D., Chaoat, M., Bensimon, A., Zamir, G., Shewach, D.S., and Kerem, B. (2011). Nucleotide deficiency promotes genomic instability in early stages of cancer development. Cell 145, 435-446.

Bier, E. (2005). Drosophila, the golden bug, emerges as a tool for human genetics. Nat Rev Genet 6, 9-23.

Binné, U.K., Classon, M.K., Dick, F.A., Wei, W., Rape, M., Kaelin, W. G. Jr, Näär, A.M., and Dyson, N.J. (2007). Retinoblastoma protein and anaphase-promoting complex physically interact and functionally cooperate during cell-cycle exit. Nat Cell Biol 9, 225-232.

Bosco, E.E., Wang, Y., Xu, H., Zilfou, J.T., Knudsen, K.E., Aronow, B. J., Lowe, S.W., and Knudsen, E.S. (2007). The retinoblastoma tumor suppressor modifies the therapeutic response of breast cancer. J Clin Invest 117, 218-228.

Bourgo, R.J., Thangavel, C., Ertel, A., Bergseid, J., McClendon, A.K., Wilkens, L., Witkiewicz, A.K., Wang, J.Y., and Knudsen, E.S. (2011). RB restricts DNA damage-initiated tumorigenesis through an LXCXE-dependent mechanism of transcriptional control. Mol 
Cell 43, 663-672.

Bunz, F., Dutriaux, A., Lengauer, C., Waldman, T., Zhou, S., Brown, J. P., Sedivy, J.M., Kinzler, K.W., and Vogelstein, B. (1998). Requirement for p53 and p21 to sustain G2 arrest after DNA damage. Science 282, 1497-1501.

Burke, J.R., Deshong, A.J., Pelton, J.G., and Rubin, S.M. (2010). Phosphorylation-induced conformational changes in the retinoblastoma protein inhibit E2F transactivation domain binding. J Biol Chem 285, 16286-16293.

Burkhart, D.L., and Sage, J. (2008). Cellular mechanisms of tumour suppression by the retinoblastoma gene. Nat Rev Cancer 8, 671-682.

Buttitta, L.A., Katzaroff, A.J., Perez, C.L., de la Cruz, A., and Edgar, B. A. (2007). A double-assurance mechanism controls cell cycle exit upon terminal differentiation in Drosophila. Dev Cell 12, 631-643.

Calo, E., Quintero-Estades, J.A., Danielian, P.S., Nedelcu, S., Berman, S.D., and Lees, J.A. (2010). Rb regulates fate choice and lineage commitment in vivo. Nature 466, 1110-1114.

Chauveinc, L., Mosseri, V., Quintana, E., Desjardins, L., Schlienger, P., Doz, F., and Dutrillaux, B. (2001). Osteosarcoma following retinoblastoma: age at onset and latency period. Ophthalmic Genet 22, 77-88.

Chen, D., Pacal, M., Wenzel, P., Knoepfler, P.S., Leone, G., and Bremner, R. (2009a). Division and apoptosis of E2f-deficient retinal progenitors. Nature 462, 925-929.

Chen, H.Z., Tsai, S.Y., and Leone, G. (2009b). Emerging roles of E2Fs in cancer: an exit from cell cycle control. Nat Rev Cancer 9, 785-797.

Chicas, A., Wang, X., Zhang, C., McCurrach, M., Zhao, Z., Mert, O., Dickins, R.A., Narita, M., Zhang, M., and Lowe, S.W. (2010). Dissecting the unique role of the retinoblastoma tumor suppressor during cellular senescence. Cancer Cell 17, 376-387.

Chin, L., Hahn, W.C., Getz, G., and Meyerson, M. (2011). Making sense of cancer genomic data. Genes Dev 25, 534-555.

Chong, J.L., Wenzel, P.L., Sáenz-Robles, M.T., Nair, V., Ferrey, A., Hagan, J.P., Gomez, Y.M., Sharma, N., Chen, H.Z., Ouseph, M., et al. (2009). E2f1-3 switch from activators in progenitor cells to repressors in differentiating cells. Nature 462, 930-934.

Christensen, J., Agger, K., Cloos, P.A., Pasini, D., Rose, S., Sennels, L., Rappsilber, J., Hansen, K.H., Salcini, A.E., and Helin, K. (2007). RBP2 belongs to a family of demethylases, specific for tri-and dimethylated lysine 4 on histone 3. Cell 128, 1063-1076.

Claudio, P.P., Zamparelli, A., Garcia, F.U., Claudio, L., Ammirati, G., Farina, A., Bovicelli, A., Russo, G., Giordano, G.G., McGinnis, D. E., et al. (2002). Expression of cell-cycle-regulated proteins pRb2/ p130, p107, p27(kip1), p53, mdm-2, and Ki-67 (MIB-1) in prostatic gland adenocarcinoma. Clin Cancer Res 8, 1808-1815.

Coschi, C.H., Martens, A.L., Ritchie, K., Francis, S.M., Chakrabarti, S., Berube, N.G., and Dick, F.A. (2010). Mitotic chromosome condensation mediated by the retinoblastoma protein is tumorsuppressive. Genes Dev 24, 1351-1363.

Dannenberg, J.H., Schuijff, L., Dekker, M., van der Valk, M., and te Riele, H. (2004). Tissue-specific tumor suppressor activity of retinoblastoma gene homologs p107 and p130. Genes Dev 18, 2952-2962.

de Nooij, J.C., Letendre, M.A., and Hariharan, I.K. (1996). A cyclindependent kinase inhibitor, Dacapo, is necessary for timely exit from the cell cycle during Drosophila embryogenesis. Cell 87,
1237-1247

Di Micco, R., Fumagalli, M., Cicalese, A., Piccinin, S., Gasparini, P., Luise, C., Schurra, C., Garre', M., Nuciforo, P.G., Bensimon, A., et al. (2006). Oncogene-induced senescence is a DNA damage response triggered by DNA hyper-replication. Nature 444, 638-642.

Dick, F.A., and Mymryk, J.S. (2011). Sweet DREAMs for Hippo. Genes Dev 25, 889-894.

Dimova, D.K., Stevaux, O., Frolov, M.V., and Dyson, N.J. (2003). Cell cycle-dependent and cell cycle-independent control of transcription by the Drosophila E2F/RB pathway. Genes Dev 17, 2308-2320.

Du, W., and Dyson, N. (1999). The role of RBF in the introduction of G1 regulation during Drosophila embryogenesis. EMBO J 18, 916-925.

Du, W., and Pogoriler, J. (2006). Retinoblastoma family genes. Oncogene 25, 5190-5200.

Dynlacht, B.D., Flores, O., Lees, J.A., and Harlow, E. (1994). Differential regulation of $\mathrm{E} 2 \mathrm{~F}$ transactivation by cyclin/cdk2 complexes. Genes Dev 8, 1772-1786.

el-Deiry, W.S., Tokino, T., Velculescu, V.E., Levy, D.B., Parsons, R., Trent, J.M., Lin, D., Mercer, W.E., Kinzler, K.W., and Vogelstein, B. (1993). WAF1, a potential mediator of $\mathrm{p} 53$ tumor suppression. Cell 75, 817-825.

Ewen, M.E., Sluss, H.K., Sherr, C.J., Matsushime, H., Kato, J., and Livingston, D.M. (1993). Functional interactions of the retinoblastoma protein with mammalian D-type cyclins. Cell 73, 487-497.

Feinberg, A.P., and Tycko, B. (2004). The history of cancer epigenetics. Nat Rev Cancer 4, 143-153.

Ferbeyre, G., de Stanchina, E., Querido, E., Baptiste, N., Prives, C., and Lowe, S.W. (2000). PML is induced by oncogenic ras and promotes premature senescence. Genes Dev 14, 2015-2027.

Ferres-Marco, D., Gutierrez-Garcia, I., Vallejo, D.M., Bolivar, J., Gutierrez-Aviño, F.J., and Dominguez, M. (2006). Epigenetic silencers and Notch collaborate to promote malignant tumours by Rb silencing. Nature 439, 430-436.

Firth, L.C., and Baker, N.E. (2005). Extracellular signals responsible for spatially regulated proliferation in the differentiating Drosophila eye. Dev Cell 8, 541-551.

Foijer, F., Wolthuis, R.M., Doodeman, V., Medema, R.H., and te Riele, $H$. (2005). Mitogen requirement for cell cycle progression in the absence of pocket protein activity. Cancer Cell 8, 455-466.

Friend, S.H., Bernards, R., Rogelj, S., Weinberg, R.A., Rapaport, J. M., Albert, D.M., and Dryja, T.P. (1986). A human DNA segment with properties of the gene that predisposes to retinoblastoma and osteosarcoma. Nature 323, 643-646.

Giangrande, P.H., Zhu, W., Schlisio, S., Sun, X., Mori, S., Gaubatz, S., and Nevins, J.R. (2004). A role for E2F6 in distinguishing G1/Sand G2/M-specific transcription. Genes Dev 18, 2941-2951.

Ginsberg, D. (2002). E2F1 pathways to apoptosis. FEBS Lett 529, 122-125.

Gonzalo, S., García-Cao, M., Fraga, M.F., Schotta, G., Peters, A.H., Cotter, S.E., Eguía, R., Dean, D.C., Esteller, M., Jenuwein, T., et al. (2005). Role of the RB1 family in stabilizing histone methylation at constitutive heterochromatin. Nat Cell Biol 7, 420-428.

Goodrich, D.W. (2003). How the other half lives, the amino-terminal domain of the retinoblastoma tumor suppressor protein. $\mathrm{J}$ Cell Physiol 197, 169-180. 
Gordon, G.M., and Du, W. (2011). Targeting Rb inactivation in cancers by synthetic lethality. Am J Cancer Res 1, 773-786.

Hallstrom, T.C., Mori, S., and Nevins, J.R. (2008). An E2F1dependent gene expression program that determines the balance between proliferation and cell death. Cancer Cell 13, 11-22.

Harper, J.W., Adami, G.R., Wei, N., Keyomarsi, K., and Elledge, S.J. (1993). The p21 Cdk-interacting protein Cip1 is a potent inhibitor of G1 cyclin-dependent kinases. Cell 75, 805-816.

Harrington, L.S., Findlay, G.M., Gray, A., Tolkacheva, T., Wigfield, S., Rebholz, H., Barnett, J., Leslie, N.R., Cheng, S., Shepherd, P.R., et al. (2004). The TSC1-2 tumor suppressor controls insulin-PI3K signaling via regulation of IRS proteins. J Cell Biol 166, 213-223.

Hassler, M., Singh, S., Yue, W.W., Luczynski, M., Lakbir, R., Sanchez-Sanchez, F., Bader, T., Pearl, L.H., and Mittnacht, S. (2007). Crystal structure of the retinoblastoma protein $\mathrm{N}$ domain provides insight into tumor suppression, ligand interaction, and holoprotein architecture. Mol Cell 28, 371-385.

Hernando, E., Nahlé, Z., Juan, G., Diaz-Rodriguez, E., Alaminos, M., Hemann, M., Michel, L., Mittal, V., Gerald, W., Benezra, R., et al. (2004). Rb inactivation promotes genomic instability by uncoupling cell cycle progression from mitotic control. Nature 430, 797-802.

Hiebert, S.W. (1993). Regions of the retinoblastoma gene product required for its interaction with the E2F transcription factor are necessary for E2 promoter repression and pRb-mediated growth suppression. Mol Cell Biol 13, 3384-3391.

Hinds, P.W., Mittnacht, S., Dulic, V., Arnold, A., Reed, S.I., and Weinberg, R.A. (1992). Regulation of retinoblastoma protein functions by ectopic expression of human cyclins. Cell 70 , 993-1006.

Hirschi, A., Cecchini, M., Steinhardt, R.C., Schamber, M.R., Dick, F. A., and Rubin, S.M. (2010). An overlapping kinase and phosphatase docking site regulates activity of the retinoblastoma protein. Nat Struct Mol Biol 17, 1051-1057.

Hsieh, T.C., Nicolay, B.N., Frolov, M.V., and Moon, N.S. (2010). Tuberous sclerosis complex 1 regulates dE2F1 expression during development and cooperates with RBF1 to control proliferation and survival. PLoS Genet 6, e1001071.

Hu, N., Gutsmann, A., Herbert, D.C., Bradley, A., Lee, W.H., and Lee, E.Y. (1994). Heterozygous Rb-1 delta 20/+ mice are predisposed to tumors of the pituitary gland with a nearly complete penetrance. Oncogene 9, 1021-1027.

lanari, A., Natale, T., Calo, E., Ferretti, E., Alesse, E., Screpanti, I., Haigis, K., Gulino, A., and Lees, J.A. (2009). Proapoptotic function of the retinoblastoma tumor suppressor protein. Cancer Cell 15, 184-194.

Isaac, C.E., Francis, S.M., Martens, A.L., Julian, L.M., Seifried, L.A., Erdmann, N., Binné, U.K., Harrington, L., Sicinski, P., Bérubé, N. G., et al. (2006). The retinoblastoma protein regulates pericentric heterochromatin. Mol Cell Biol 26, 3659-3671.

Ishida, S., Huang, E., Zuzan, H., Spang, R., Leone, G., West, M., and Nevins, J.R. (2001). Role for E2F in control of both DNA replication and mitotic functions as revealed from DNA microarray analysis. Mol Cell Biol 21, 4684-4699.

Iwase, S., Lan, F., Bayliss, P., de la Torre-Ubieta, L., Huarte, M., Qi, H. H., Whetstine, J.R., Bonni, A., Roberts, T.M., and Shi, Y. (2007). The X-linked mental retardation gene SMCX/JARID1C defines a family of histone $\mathrm{H} 3$ lysine 4 demethylases. Cell 128, 1077-1088.

Julien, L.A., Carriere, A., Moreau, J., and Roux, P.P. (2010).
mTORC1-activated S6K1 phosphorylates Rictor on threonine 1135 and regulates mTORC2 signaling. Mol Cell Biol 30, 908-921.

Kaelin, W.G. Jr. (2005). The concept of synthetic lethality in the context of anticancer therapy. Nat Rev Cancer 5, 689-698.

Kamijo, T., Weber, J.D., Zambetti, G., Zindy, F., Roussel, M.F., and Sherr, C.J. (1998). Functional and physical interactions of the ARF tumor suppressor with p53 and Mdm2. Proc Natl Acad Sci U S A 95, 8292-8297.

Kanber, D., Berulava, T., Ammerpohl, O., Mitter, D., Richter, J., Siebert, R., Horsthemke, B., Lohmann, D., and Buiting, K. (2009). The human retinoblastoma gene is imprinted. PLoS Genet 5, e1000790.

Kato, J., Matsushime, H., Hiebert, S.W., Ewen, M.E., and Sherr, C.J. (1993). Direct binding of cyclin D to the retinoblastoma gene product $(\mathrm{pRb})$ and $\mathrm{pRb}$ phosphorylation by the cyclin D-dependent kinase CDK4. Genes Dev 7, 331-342.

Kaye, F.J., and Harbour, J.W. (2004). For whom the bell tolls: susceptibility to common adult cancers in retinoblastoma survivors. J Natl Cancer Inst 96, 342-343.

Klose, R.J., Yan, Q., Tothova, Z., Yamane, K., Erdjument-Bromage, H., Tempst, P., Gilliland, D.G., Zhang, Y., and Kaelin, W.G. Jr. (2007). The retinoblastoma binding protein RBP2 is an H3K4 demethylase. Cell 128, 889-900.

Knudsen, E.S., and Wang, J.Y. (2010). Targeting the RB-pathway in cancer therapy. Clin Cancer Res 16, 1094-1099.

Knudson, A.G. Jr. (1971). Mutation and cancer: statistical study of retinoblastoma. Proc Natl Acad Sci U S A 68, 820-823.

Korenjak, M., Taylor-Harding, B., Binné, U.K., Satterlee, J.S., Stevaux, O., Aasland, R., White-Cooper, H., Dyson, N., and Brehm, A. (2004). Native E2F/RBF complexes contain Mybinteracting proteins and repress transcription of developmentally controlled E2F target genes. Cell 119, 181-193.

Lalande, M., Dryja, T.P., Schreck, R.R., Shipley, J., Flint, A., and Latt, S.A. (1984). Isolation of human chromosome 13-specific DNA sequences cloned from flow sorted chromosomes and potentially linked to the retinoblastoma locus. Cancer Genet Cytogenet 13, 283-295.

Lane, M.E., Sauer, K., Wallace, K., Jan, Y.N., Lehner, C.F., and Vaessin, H. (1996). Dacapo, a cyclin-dependent kinase inhibitor, stops cell proliferation during Drosophila development. Cell 87, 1225-1235.

Laurie, N.A., Donovan, S.L., Shih, C.S., Zhang, J., Mills, N., Fuller, C., Teunisse, A., Lam, S., Ramos, Y., Mohan, A., et al. (2006). Inactivation of the p53 pathway in retinoblastoma. Nature 444 , 61-66.

Lee, W.H., Bookstein, R., Hong, F., Young, L.J., Shew, J.Y., and Lee, E.Y. (1987). Human retinoblastoma susceptibility gene: cloning, identification, and sequence. Science 235, 1394-1399.

Lewis, P.W., Beall, E.L., Fleischer, T.C., Georlette, D., Link, A.J., and Botchan, M.R. (2004). Identification of a Drosophila Myb-E2F2/ RBF transcriptional repressor complex. Genes Dev 18, 2929-2940.

Li, B., Gordon, G.M., Du, C.H., Xu, J., and Du, W. (2010). Specific killing of $\mathrm{Rb}$ mutant cancer cells by inactivating TSC2. Cancer Cell 17, 469-480.

Li, J., Ran, C., Li, E., Gordon, F., Comstock, G., Siddiqui, H., Cleghorn, W., Chen, H.Z., Kornacker, K., Liu, C.G., et al. (2008). Synergistic function of E2F7 and E2F8 is essential for cell survival 
and embryonic development. Dev Cell 14, 62-75.

Lin, W., Cao, J., Liu, J., Beshiri, M.L., Fujiwara, Y., Francis, J., Cherniack, A.D., Geisen, C., Blair, L.P., Zou, M.R., et al. (2011). Loss of the retinoblastoma binding protein 2 (RBP2) histone demethylase suppresses tumorigenesis in mice lacking $\mathrm{Rb} 1$ or Men1. Proc Natl Acad Sci U S A 108, 13379-13386.

Litovchick, L., Florens, L.A., Swanson, S.K., Washburn, M.P., and DeCaprio, J.A. (2011). DYRK1A protein kinase promotes quiescence and senescence through DREAM complex assembly. Genes Dev 25, 801-813.

Litovchick, L., Sadasivam, S., Florens, L., Zhu, X., Swanson, S.K., Velmurugan, S., Chen, R., Washburn, M.P., Liu, X.S., and DeCaprio, J.A. (2007). Evolutionarily conserved multisubunit RBL2/p130 and E2F4 protein complex represses human cell cycle-dependent genes in quiescence. Mol Cell 26, 539-551.

Longworth, M.S., Herr, A., Ji, J.Y., and Dyson, N.J. (2008). RBF1 promotes chromatin condensation through a conserved interaction with the Condensin II protein dCAP-D3. Genes Dev 22, 1011-1024.

Lopez-Bigas, N., Kisiel, T.A., Dewaal, D.C., Holmes, K.B., Volkert, T. L., Gupta, S., Love, J., Murray, H.L., Young, R.A., and Benevolenskaya, E.V. (2008). Genome-wide analysis of the H3K4 histone demethylase RBP2 reveals a transcriptional program controlling differentiation. Mol Cell 31, 520-530.

Ludlow, J.W., Glendening, C.L., Livingston, D.M., and DeCarprio, J.A. (1993). Specific enzymatic dephosphorylation of the retinoblastoma protein. Mol Cell Biol 13, 367-372.

Lukas, J., Parry, D., Aagaard, L., Mann, D.J., Bartkova, J., Strauss, M., Peters, G., and Bartek, J. (1995). Retinoblastoma-proteindependent cell-cycle inhibition by the tumour suppressor $\mathrm{p} 16$. Nature 375, 503-506.

Magnaghi-Jaulin, L., Groisman, R., Naguibneva, I., Robin, P., Lorain, S., Le Villain, J.P., Troalen, F., Trouche, D., and Harel-Bellan, A. (1998). Retinoblastoma protein represses transcription by recruiting a histone deacetylase. Nature 391, 601-605.

Manning, A.L., Longworth, M.S., and Dyson, N.J. (2010). Loss of pRB causes centromere dysfunction and chromosomal instability. Genes Dev 24, 1364-1376.

Milet, C., Rincheval-Arnold, A., Mignotte, B., and Guénal, I. (2010). The Drosophila retinoblastoma protein induces apoptosis in proliferating but not in post-mitotic cells. Cell Cycle 9, 97-103.

Miller, C.W., Simon, K., Aslo, A., Kok, K., Yokota, J., Buys, C.H., Terada, M., and Koeffler, H.P. (1992). p53 mutations in human lung tumors. Cancer Res 52, 1695-1698.

Moon, N.S., Di Stefano, L., and Dyson, N. (2006). A gradient of epidermal growth factor receptor signaling determines the sensitivity of rbf1 mutant cells to E2F-dependent apoptosis. Mol Cell Biol 26, 7601-7615.

Moon, N.S., Frolov, M.V., Kwon, E.J., Di Stefano, L., Dimova, D.K., Morris, E.J., Taylor-Harding, B., White, K., and Dyson, N.J. (2005). Drosophila E2F1 has context-specific pro- and antiapoptotic properties during development. Dev Cell 9, 463-475.

Moroni, M.C., Hickman, E.S., Lazzerini Denchi, E., Caprara, G., Colli, E., Cecconi, F., Müller, H., and Helin, K. (2001). Apaf-1 is a transcriptional target for E2F and p53. Nat Cell Biol 3, 552-558.

Müller, H., Bracken, A.P., Vernell, R., Moroni, M.C., Christians, F., Grassilli, E., Prosperini, E., Vigo, E., Oliner, J.D., and Helin, K. (2001). E2Fs regulate the expression of genes involved in differentiation, development, proliferation, and apoptosis. Genes Dev 15, 267-285.

Mulligan, G., and Jacks, T. (1998). The retinoblastoma gene family: cousins with overlapping interests. Trends Genet 14, 223-229.

Narita, M., Nũnez, S., Heard, E., Narita, M., Lin, A.W., Hearn, S.A., Spector, D.L., Hannon, G.J., and Lowe, S.W. (2003). Rb-mediated heterochromatin formation and silencing of E2F target genes during cellular senescence. Cell 113, 703-716.

Nicolay, B.N., Bayarmagnai, B., Islam, A.B., Lopez-Bigas, N., and Frolov, M.V. (2011). Cooperation between dE2F1 and Yki/Sd defines a distinct transcriptional program necessary to bypass cell cycle exit. Genes Dev 25, 323-335.

Nicolay, B.N., Bayarmagnai, B., Moon, N.S., Benevolenskaya, E.V., and Frolov, M.V. (2010). Combined inactivation of pRB and hippo pathways induces dedifferentiation in the Drosophila retina. PLoS Genet 6, e1000918.

Nogueira, V., Park, Y., Chen, C.C., Xu, P.Z., Chen, M.L., Tonic, I., Unterman, T., and Hay, N. (2008). Akt determines replicative senescence and oxidative or oncogenic premature senescence and sensitizes cells to oxidative apoptosis. Cancer Cell 14, $458-470$.

Ozcan, U., Ozcan, L., Yilmaz, E., Düvel, K., Sahin, M., Manning, B.D., and Hotamisligil, G.S. (2008). Loss of the tuberous sclerosis complex tumor suppressors triggers the unfolded protein response to regulate insulin signaling and apoptosis. Mol Cell 29, 541-551.

Pan, D. (2010). The hippo signaling pathway in development and cancer. Dev Cell 19, 491-505.

Pearson, M., Carbone, R., Sebastiani, C., Cioce, M., Fagioli, M., Saito, S., Higashimoto, Y., Appella, E., Minucci, S., Pandolfi, P.P., et al. (2000). PML regulates p53 acetylation and premature senescence induced by oncogenic Ras. Nature 406, 207-210.

Pickering, M.T., and Kowalik, T.F. (2006). Rb inactivation leads to E2F1-mediated DNA double-strand break accumulation. Oncogene 25, 746-755.

Polyak, K., Lee, M.H., Erdjument-Bromage, H., Koff, A., Roberts, J. M., Tempst, P., and Massagué, J. (1994). Cloning of p27Kip1, a cyclin-dependent kinase inhibitor and a potential mediator of extracellular antimitogenic signals. Cell 78, 59-66.

Qin, X.Q., Chittenden, T., Livingston, D.M., and Kaelin, W.G. Jr. (1992). Identification of a growth suppression domain within the retinoblastoma gene product. Genes Dev 6, 953-964.

Racek, T., Buhlmann, S., Rüst, F., Knoll, S., Alla, V., and Pützer, B.M. (2008). Transcriptional repression of the prosurvival endoplasmic reticulum chaperone GRP78/BIP by E2F1. J Biol Chem 283, 34305-34314.

Ren, B., Cam, H., Takahashi, Y., Volkert, T., Terragni, J., Young, R.A., and Dynlacht, B.D. (2002). E2F integrates cell cycle progression with DNA repair, replication, and G(2)/M checkpoints. Genes Dev 16, 245-256.

Robertson, K.D., Ait-Si-Ali, S., Yokochi, T., Wade, P.A., Jones, P.L., and Wolffe, A.P. (2000). DNMT1 forms a complex with Rb, E2F1 and HDAC1 and represses transcription from E2F-responsive promoters. Nat Genet 25, 338-342.

Rogoff, H.A., Pickering, M.T., Debatis, M.E., Jones, S., and Kowalik, T.F. (2002). E2F1 induces phosphorylation of $p 53$ that is coincident with p53 accumulation and apoptosis. Mol Cell Biol 22, 5308-5318.

Rubin, S.M., Gall, A.L., Zheng, N., and Pavletich, N.P. (2005). 
Structure of the Rb C-terminal domain bound to E2F1-DP1: a mechanism for phosphorylation-induced E2F release. Cell 123, 1093-1106.

Ruthenburg, A.J., Li, H., Patel, D.J., and Allis, C.D. (2007). Multivalent engagement of chromatin modifications by linked binding modules. Nat Rev Mol Cell Biol 8, 983-994.

Sage, J., Miller, A.L., Pérez-Mancera, P.A., Wysocki, J.M., and Jacks, T. (2003). Acute mutation of retinoblastoma gene function is sufficient for cell cycle re-entry. Nature 424, 223-228.

Sarbassov, D.D., Guertin, D.A., Ali, S.M., and Sabatini, D.M. (2005). Phosphorylation and regulation of Akt/PKB by the rictor-mTOR complex. Science 307, 1098-1101.

Schvartzman, J.M., Duijf, P.H., Sotillo, R., Coker, C., and Benezra, R. (2011). Mad2 is a critical mediator of the chromosome instability observed upon $\mathrm{Rb}$ and p53 pathway inhibition. Cancer Cell 19, 701-714.

Searle, J.S., Li, B., and Du, W. (2010). Targeting Rb mutant cancers by inactivating TSC2. Oncotarget 1, 228-232.

Serrano, M., Hannon, G.J., and Beach, D. (1993). A new regulatory motif in cell-cycle control causing specific inhibition of cyclin D/ CDK4. Nature 366, 704-707.

Shah, O.J., Wang, Z., and Hunter, T. (2004). Inappropriate activation of the TSC/Rheb/mTOR/S6K cassette induces IRS1/2 depletion, insulin resistance, and cell survival deficiencies. Curr Biol 14, 1650-1656.

Sharma, A., Yeow, W.S., Ertel, A., Coleman, I., Clegg, N., Thangavel, C., Morrissey, C., Zhang, X., Comstock, C.E., Witkiewicz, A.K., et al. (2010). The retinoblastoma tumor suppressor controls androgen signaling and human prostate cancer progression. J Clin Invest 120, 4478-4492.

Sherr, C.J., and McCormick, F. (2002). The RB and p53 pathways in cancer. Cancer Cell 2, 103-112.

Stanelle, J., Stiewe, T., Theseling, C.C., Peter, M., and Pützer, B.M. (2002). Gene expression changes in response to E2F1 activation. Nucleic Acids Res 30, 1859-1867.

Steele, L., Sukhanova, M.J., Xu, J., Gordon, G.M., Huang, Y., Yu, L., and Du, W. (2009). Retinoblastoma family protein promotes normal R8-photoreceptor differentiation in the absence of rhinoceros by inhibiting dE2F1 activity. Dev Biol 335, 228-236.

Stevaux, O., Dimova, D., Frolov, M.V., Taylor-Harding, B., Morris, E., and Dyson, N. (2002). Distinct mechanisms of E2F regulation by Drosophila RBF1 and RBF2. EMBO J 21, 4927-4937.

Stirzaker, C., Millar, D.S., Paul, C.L., Warnecke, P.M., Harrison, J., Vincent, P.C., Frommer, M., and Clark, S.J. (1997). Extensive DNA methylation spanning the $\mathrm{Rb}$ promoter in retinoblastoma tumors. Cancer Res 57, 2229-2237.

Stott, F.J., Bates, S., James, M.C., McConnell, B.B., Starborg, M., Brookes, S., Palmero, I., Ryan, K., Hara, E., Vousden, K.H., et al. (1998). The alternative product from the human CDKN2A locus, p14(ARF), participates in a regulatory feedback loop with p53 and MDM2. EMBO J 17, 5001-5014.

Sukhanova, M.J., Steele, L.J., Zhang, T., Gordon, G.M., and Du, W.. RBF and Rno promote photoreceptor differentiation onset through modulating EGFR signaling in the Drosophila developing eye. Dev Biol. Sep 2, 2011. [Epub ahead of print].

Takahashi, Y., Rayman, J.B., and Dynlacht, B.D. (2000). Analysis of promoter binding by the E2F and $\mathrm{pRB}$ families in vivo: distinct $\mathrm{E} 2 \mathrm{~F}$ proteins mediate activation and repression. Genes Dev 14,
804-816.

Talluri, S., Isaac, C.E., Ahmad, M., Henley, S.A., Francis, S.M., Martens, A.L., Bremner, R., and Dick, F.A. (2010). A G1 checkpoint mediated by the retinoblastoma protein that is dispensable in terminal differentiation but essential for senescence. Mol Cell Biol 30, 948-960.

Tanaka, H., Matsumura, I., Ezoe, S., Satoh, Y., Sakamaki, T., Albanese, C., Machii, T., Pestell, R.G., and Kanakura, Y. (2002). E2F1 and c-Myc potentiate apoptosis through inhibition of NFkappaB activity that facilitates MnSOD-mediated ROS elimination. Mol Cell 9, 1017-1029.

Tanaka-Matakatsu, M., Xu, J., Cheng, L., and Du, W. (2009). Regulation of apoptosis of rbf mutant cells during Drosophila development. Dev Biol 326, 347-356.

Taubert, S., Gorrini, C., Frank, S.R., Parisi, T., Fuchs, M., Chan, H.M., Livingston, D.M., and Amati, B. (2004). E2F-dependent histone acetylation and recruitment of the Tip60 acetyltransferase complex to chromatin in late G1. Mol Cell Biol 24, 4546- 4556.

Taylor, B.S., Schultz, N., Hieronymus, H., Gopalan, A., Xiao, Y., Carver, B.S., Arora, V.K., Kaushik, P., Cerami, E., Reva, B., et al. (2010). Integrative genomic profiling of human prostate cancer. Cancer Cell 18, 11-22.

Thomas, D.M., Carty, S.A., Piscopo, D.M., Lee, J.S., Wang, W.F., Forrester, W.C., and Hinds, P.W. (2001). The retinoblastoma protein acts as a transcriptional coactivator required for osteogenic differentiation. Mol Cell 8, 303-316.

Toyoshima, H., and Hunter, T. (1994). p27, a novel inhibitor of G1 cyclin-Cdk protein kinase activity, is related to p21. Cell 78, 67-74.

Treins, C., Warne, P.H., Magnuson, M.A., Pende, M., and Downward, J. (2010). Rictor is a novel target of p70 S6 kinase-1. Oncogene 29, 1003-1016.

Tsai, K.Y., Hu, Y., Macleod, K.F., Crowley, D., Yamasaki, L., and Jacks, T. (1998). Mutation of E2f-1 suppresses apoptosis and inappropriate $\mathrm{S}$ phase entry and extends survival of $\mathrm{Rb}$-deficient mouse embryos. Mol Cell 2, 293-304.

Tschöp, K., Conery, A.R., Litovchick, L., Decaprio, J.A., Settleman, J., Harlow, E., and Dyson, N. (2011). A kinase shRNA screen links LATS2 and the pRB tumor suppressor. Genes Dev 25, 814-830.

van den Heuvel, S., and Dyson, N.J. (2008). Conserved functions of the pRB and E2F families. Nat Rev Mol Cell Biol 9, 713-724.

van Harn, T., Foijer, F., van Vugt, M., Banerjee, R., Yang, F., Oostra, A., Joenje, H., and te Riele, H. (2010). Loss of Rb proteins causes genomic instability in the absence of mitogenic signaling. Genes Dev 24, 1377-1388.

Vernier, M., Bourdeau, V., Gaumont-Leclerc, M.F., Moiseeva, O., Bégin, V., Saad, F., Mes-Masson, A.M., and Ferbeyre, G. (2011). Regulation of E2Fs and senescence by PML nuclear bodies. Genes Dev 25, 41-50.

Voas, M.G., and Rebay, I. (2003). The novel plant homeodomain protein rhinoceros antagonizes Ras signaling in the Drosophila eye. Genetics 165, 1993-2006.

Wang, H., Bauzon, F., Ji, P., Xu, X., Sun, D., Locker, J., Sellers, R.S., Nakayama, K., Nakayama, K.I., Cobrinik, D., et al. (2010). Skp2 is required for survival of aberrantly proliferating Rb1-deficient cells and for tumorigenesis in Rb1 +/- mice. Nat Genet 42, 83-88.

Wei, W., Ayad, N.G., Wan, Y., Zhang, G.J., Kirschner, M.W., and Kaelin, W.G. Jr. (2004). Degradation of the SCF component Skp2 in cell-cycle phase $\mathrm{G} 1$ by the anaphase-promoting complex. 
Nature 428, 194-198.

Wikenheiser-Brokamp, K.A. (2004). Rb family proteins differentially regulate distinct cell lineages during epithelial development. Development 131, 4299-4310.

Wikenheiser-Brokamp, K.A. (2006a). Retinoblastoma family proteins: insights gained through genetic manipulation of mice. Cell Mol Life Sci 63, 767-780.

Wikenheiser-Brokamp, K.A. (2006b). Retinoblastoma regulatory pathway in lung cancer. Curr Mol Med 6, 783-793.

Williams, B.O., Remington, L., Albert, D.M., Mukai, S., Bronson, R.T., and Jacks, T. (1994). Cooperative tumorigenic effects of germline mutations in Rb and p53. Nat Genet 7, 480-484.

Wirt, S.E., Adler, A.S., Gebala, V., Weimann, J.M., Schaffer, B.E., Saddic, L.A., Viatour, P., Vogel, H., Chang, H.Y., Meissner, A., et al. (2010). G1 arrest and differentiation can occur independently of $\mathrm{Rb}$ family function. J Cell Biol 191, 809-825.

Xie, W., Jiang, P., Miao, L., Zhao, Y., Zhimin, Z., Qing, L., Zhu, W.G., and Wu, M. (2006). Novel link between E2F1 and Smac/DIABLO: proapoptotic Smac/DIABLO is transcriptionally upregulated by E2F1. Nucleic Acids Res 34, 2046-2055.
Yamasaki, L., Bronson, R., Williams, B.O., Dyson, N.J., Harlow, E., and Jacks, T. (1998). Loss of E2F-1 reduces tumorigenesis and extends the lifespan of Rb1(+/-) mice. Nat Genet 18, 360-364.

Yamasaki, L., Jacks, T., Bronson, R., Goillot, E., Harlow, E., and Dyson, N.J. (1996). Tumor induction and tissue atrophy in mice lacking E2F-1. Cell 85, 537-548.

Young, A.P., and Longmore, G.D. (2004). Ras protects Rb family null fibroblasts from cell death: a role for AP-1. J Biol Chem 279, 10931-10938.

Zhang, H.S., Gavin, M., Dahiya, A., Postigo, A.A., Ma, D., Luo, R.X., Harbour, J.W., and Dean, D.C. (2000). Exit from G1 and S phase of the cell cycle is regulated by repressor complexes containing HDAC-Rb-hSWI/SNF and Rb-hSWI/SNF. Cell 101, 79-89.

Zhang, Y., Xiong, Y., and Yarbrough, W.G. (1998). ARF promotes MDM2 degradation and stabilizes p53: ARF-INK4a locus deletion impairs both the $\mathrm{Rb}$ and $\mathrm{p} 53$ tumor suppression pathways. Cell 92 , 725-734.

Zhu, L., Harlow, E., and Dynlacht, B.D. (1995). p107 uses a p21CIP1related domain to bind cyclin/cdk2 and regulate interactions with E2F. Genes Dev 9, 1740-1752. 